\title{
HYPOLIPIDMIC EFFECT OF JAMUN SYZYGIUM CUMINI
}

\author{
M. A. Hammam, S. A. El-Kadousy, S. M. El-Sayed and R. M. Rashed \\ Biochemistry Department, Faculty of Agriculture, Menoufia University, \\ Shibin El-Kom, Egypt
}

Received: Oct. 29 , 2019

Accepted: Nov. 2, 2019

\begin{abstract}
The present work aims to study the potential effect of jamun Syzygium cumini seeds and leaves to give more protection against hyperlipidemia. Twenty male albino rats were used over 30 days period. The animals were divided into (4) groups, wherein groups number (1) represent control which were fed basal diet, while group number (2) was received high fat diet to serve as hyperlipidemic group. Other two groups allowed to feed high fat diet supplemented with jamun seeds and leaves, group number (3) treated simultaneously with jamun seeds, fourth group treated with jamun leaves. At the end of the experimental period, blood samples were collected to determine lipid profile, liver functions and determine the kidney functions include urea nitrogen and creatinine. From the obtained results we concluded that group of rats fed on high fat diet were considered as a major risk factor for hyperlipidemia disease. Our results could be summarized that jamun seeds and jamun leaves were considered the best for causing a reduction of TC, TG and LDL. Also, liver functions has been improved and there were significant reduction GOT, GPT and ALP activity than that of positive control group. It could be concluded that jamun seeds and jamun leaves under study are useful for the treatment of hyperlipidemia.
\end{abstract}

Key words : Jamun - Triglycerides - Cholesterol - liver.

\section{INTRODUCTION}

Jamun, Syzygium cumini commonly known as Black berry, Black plum, Jambul or Java Plum, is large evergreen, glabrous tree, it is distributed throughout India, Sri Lanka, Malaya, and Australia. Annually the trees produce oblong or ellipsoid fruits (berries). They are green when raw and purplish black when fully ripe. The ripe fruits are sweetish sour to taste. Studies have shown that the berries contain carbohydrates, minerals and the pharmacologically active phytochemicals like flavonoids, terpenes, and anthocyanins. The plant is rich in compounds containing anthocyanins, glucoside, ellagic acid, isoquercetin, kaemferol and myrecetin. The seeds are claimed to contain alkaloid, jambosine and glycoside jambolin or antimellin, which halts the diastatic conversion of starch into sugar. The vast number of literatures found in the database revealed that the extracts of different parts of jamun showed significant pharmacological actions. Krauss, and Huschmand., (2001). Jamun Syzygium cumini $L$. is an indigenous minor fruit of India. Which belongs to family Myrtaceae commonly known as jamun, jaman, duhat (Hindi) and black plum, Indian black berry, jambolan, jambolan plum, javaplum, Malabar plum, Portuguese plum in English Jamun is large, evergreen widely distributed forest tree of India, Srilanka, Malaysia and Australia which is also cultivated for its edible fruits. The tree was introduced from India and tropical Asia to southern Africa for its edible and attractive fruits. It has been successfully introduced to many tropical countries like West Indies, East and West Africa and some subtropical regions like Florida, California, Algeria and Israel for its commercial importance. Sharma et al., (2012). Leaves are rich in various 
flavonoids, terpenoids and phenolics such as sitosterol, betulinic acid, crategolic acid, quercetin, myricetin, methyl gallate, kaempferol. Gupta and Sharma., (2013). Seeds have been reported to be rich in flavonoids, a wellknown antioxidant, which accounts for the scavenging of free radicals and protective effect on antioxidant enzymes and also found to have high total phenolics with significant antioxidant activity and are fairly rich in protein and calcium. Ravi et al., (2004). Alcoholic extract of Syzygium cumini seed showed better response in reducing tissue damage in diabetic rat brain in compare with the aqueous extract. The results of both extract were better than glibenclamide $(600 \mu \mathrm{g} / \mathrm{kg})$. Stanley et al., (2003). Hypocholesterolemic and hypolipidemic effects of Syzygium cumini seeds have been attributed to the water soluble gummy fibers present in them. The viscosity measurement studies indicated that water-soluble gummy fiber isolated from S. cumini seeds is a highly viscous material, Highly viscous watersoluble fibers present in plant materials have been shown to reduce serum cholesterol levels and lipid levels in animals and human beings, The waterinsoluble neutral detergent fibers (NDFs) had no significant hypocholesterolemic and hypolipidemic effects. This is based on the observations of research study that $6 \%, 12 \%$, and $18 \%$ water-soluble gummy fibers lowered blood cholesterol and lipid levels whereas $2.25 \%, 5 \%$, and $10 \%$ water-insoluble NDFs did not exhibit any such activity. Pandey and Khan, (2002).

The aim of the present investigation was to evaluate the influence of jamun seeds and jamun leaves on serum lipids, liver and kidney functions of hyperlipidemic rats on biochemical and biological changes that may occur to rats fed on high fat diet.

\section{MATERIALS AND METHODS Materials}

Jamun seeds and jamun leaves were collected from research center department of medical and aromatic plants. Giza Egypt. The seeds were dried and milled.

\section{Methods \\ Proximate composition:}

The methods of the Association of Official Analytical Chemists AOAC, (1990) were used for proximate analysis. jamun seeds and jamun leaves samples (5 grams) was used for determination of moisture content by weighing in crucible and drying in oven at $105^{\circ} \mathrm{C}$, until a constant weight was obtained. Determination of ash content was done by ashing at $550^{\circ} \mathrm{C}$ for $3 \mathrm{~h}$. The Kjeldahl method was used to determine the protein content. The crude fiber content of the samples was determined by digestion method and the fat was done by Soxhlet extraction method. All determinations were done in triplicate. The carbohydrate content of the test sample was determined by estimation using the arithmetic difference method .
$\% \mathrm{CHO}=100-(\%$ fat. $+\%$ ash $+\%$ fiber + $\%$ protein)

\section{Quantitative identification of phenolics compounds by HPLC.}

Amodified method of Zuo, et al, (2002), the analysis was carried out using HPLC (Ashimazdzu IC20 AT ) equipped with a Luna TM 5 um C18,25 cm×4.6 mm i.d (phenomenex, Torrance, CA,USA) column. S.PD-20 UV Visible detector was used. A gradient elution was carried out using the following solvent systems: Mobile phase A (acetonitrile $I$ acetic acid /double distilled water -9/2/89 v/v/v), mopile phase B (acetonitrilel acetic acid I double distilled water $-80 / 2 / 18 \mathrm{v} / \mathrm{v} / \mathrm{v}$ ). The mobile phase composition was started at $100 \%$ solvent A.32\%mobile phase Band held at this composition for $10 \mathrm{~min}$. The 
flow rate of the mobile phase was 1 $\mathrm{ml} / \mathrm{min}$ and the temperature at the column preformed at $35 \pm 0.5^{\circ} \mathrm{C}$. The identification of individual components was carried out by comparing the retention times and UV- absorbance of unknown peaks with peaks obtained from the mixed known standard under the same condition.

\section{Antioxidant activity of plant extracts:}

2,2-diphenly -1- picrylhydrazyl

(DPPH) redical seavenging activity:

The antioxidant activity of the seeds and Leaves extracts, and the standard were assessed on the basis of the redical seavinging effect of the stable 2,2diphenyl -2- picrylhydrazyl (DPPH)- free radical activity by modified method, Braca et al. (2001). The diluted working solution of the test extracts were prepared in methanol. Ascorbic acid was used as standard, was mixed with $1.0 \mathrm{ml}$ of sample solution and standard solution separately. These solution mixtures were kept in dark for $30 \mathrm{~min}$ and optical density was measured at $517 \mathrm{~nm}$ usings spectrophotometer. Methanol $(1 \mathrm{ml})$ with DPPH solution $(0.002 \%, 1.0 \mathrm{ml})$ was used as blank. The optical density was recorded and \%inhibition was calculated using the formula given below:

Percent (\%) inhibition of DPPH activity = A-B/A $\times 100$

Where $A=$ optical density of the blank and $B=$ optinal density of the sample.

\section{Biological Evaluation}

\section{Animals:}

Adult male albino rats Sprague Dawely strain weighing between (90 100) $\mathrm{gm}$, were obtained from the animal house of Egyptian Organization for biological Products and Vaccines (VACSERA) Cairo, Egypt. The animals study were taken after the prior approval of Animal Ethics Committee. The animals were kept in wire cages with wire bottom. The diet was introduced to the rats in special feed cup that kept food spilling to a minimum, water was provided to the rats by means of glass tube projecting through wire cage, an inverted bottle supported one side of the cage.

\section{Experimental Design:}

Twenty rats were divided into four groups : group (A) control fed on basal diet, groups (B, C and D ) were allowed to feed hyperlipidemic diet to induce hyperlipidemic through the feeding period. One of each experiment continued feeding hyperlipidemic diet without any supplementation saved as hyperlipidemic group (B) and the other two groups of each experiment were allowed to feed hyperlipidemic diet with jamun seeds ( $5 \%$ of meal) as group (C), jamun leaves ( $5 \%$ of meal) as group (D). Standard diet composition was described in (Table 1) by Campbell (1961) and hyperlipidemic diet was described by Nakamura et al., (1989) as follows:

Table (1). Standard and hyperlipidemic diet Composition.

\begin{tabular}{|c||c|c|}
\hline \multicolumn{1}{|c||}{ Ingredient } & Standard diet & Hyperlipidemic diet \\
\hline \hline Carbohydrates as starch & $80 \%$ & $66.75 \%$ \\
\hline Protein as casein & $10 \%$ & $10 \%$ \\
\hline Fats as corn oil & $5 \%$ & $5 \%$ \\
\hline Salt mixture & $4 \%$ & $4 \%$ \\
\hline \hline Vitamins mixture & $1 \%$ & $1 \%$ \\
\hline Cholesterol & $0 \%$ & $3 \%$ \\
\hline Bile salts & $0 \%$ & $0.25 \%$ \\
\hline Sheep tail fat & $0 \%$ & $10 \%$ \\
\hline
\end{tabular}




\section{Blood sampling and analysis}

Blood samples were collected after $\mathbf{3 0}$ dsys in tubes contain heparin as an anticoagulant from the eye plexuses under diethyl ether anesthesia and then centrifuged at $3000 \mathrm{rpm}$ for $20 \mathrm{~min}$. to obtain plasma, which was kept frozen until analysis. The total cholesterol was analyzed calorimetrically according to Allain et al., (1974), method. HDL cholesterol was determined according to Lopez et al., (1977) method. LDL cholesterol was calculated as : LDL-C = Total C - ( HDL-C + triglyceride/5 ). Risk ratio was calculated according the formula of Lopez et al., (1977) which Risk ratio $=$ total cholesterol $/ \mathrm{HDL}$ cholesterol. Atherogenic Index (AI) was calculated according to Lopez et al., (1977) using following equation: Atherogenic index = LDL-C I HDL-C. The triglycerides were analyzed according to Fossati, and Prencipe (1982) method. Alanineaminotransferase (ALT) and aspartateaminotransferase (AST) activities were measured according to the method described by Retiman and Frankel (1957). Alkaline phosphatase (ALP) activity was measured by the method of Hausamen et al., (1967). Urea and creatinine were determined according to Young (2001).

\section{Statistical analysis}

The results of the animal experiments were expressed as the Mean \pm SE and they were analyzed statistically using the one-way analysis of variance ANOVA followed by Duncan's test. In all cases $p<0.05$ was used as the criterion of statistical significance.

\section{RESULTS AND DISCUSSION Proximate composition of Moringa seeds:}

The obtained results in Table (2) indicated that:

Syzygium cumini (L.). seeds contain moisture (13.72\%), crude fiber $(5.15 \%)$, ash $(3.2 \%)$, crude protein $(2.18 \%)$, crude fat $(0.87 \%)$ and total carbohydrate (88.6\%). Syzygium cumini (L.). leaves consisted of moisture $(8.488 \%)$, crude fiber $(17.65 \%)$, ash $(6.5 \%)$, crude protein $(1.89 \%)$, crude fat $(0.57 \%)$ and total carbohydrate (73.39\%).

Theses result were in accordance with earlier findings reported by Prased et al, (2010). Who depicted that Juman seeds consisted of $9.34 \pm 1.99 \%$ moisture, 2.42 $\pm 0.44 \%$ crude protein, $0.92 \pm 0.52 \%$ crude fat, $6.08 \pm 1.11 \%$ crude fiber and 2.93 $\pm 0.82 \%$ ash. Also Ahmed et al., (2015). Who depicted that Jumun seed consisted of moisture (16.34 $\pm 0.49 \%)$, crude protein $(1.97 \pm 0.59 \%)$, crude fat $(2.18 \pm 0.06 \%)$.

Table (2): Proximate analysis of Syzygium cumini (L.). seeds\& leaves

\begin{tabular}{|c|c|c|}
\hline \multirow{2}{*}{ Components } & \multicolumn{2}{|c|}{ Percentage (W/W \%) } \\
\cline { 2 - 3 } & Seeds & Leaves \\
\hline \hline Moisture & 13.72 & 8.488 \\
\hline Crude fiber & 5.15 & 17.65 \\
\hline Ash & 3.2 & 6.5 \\
\hline Crude protein & 2.18 & 1.89 \\
\hline Crude fat & 0.87 & 0.57 \\
\hline Total carbohydrate & 88.6 & 73.39 \\
\hline
\end{tabular}


Phenolic compounds of Syzygium cumini (L.) seeds and leaves.

Phenolic compounds in methanol extracts of seeds and leaves for Syzygium cumini were analyzed by High Performance Liquid Chromatography (HPLC), and concentration of all tested phenolic compounds are given in Table (3). From this table it was found that Syzygium cumini seeds contains 13 phenolic compounds where Syzygium cumini leaves contains 12 phenolic compounds, analysis of Syzygium cumini seeds showed that benzoic acid, gallic acid, P-hydroxy benzoic acid, vanillin and ellagic acid are the major phenolic compounds meanwhile gallic acid, rutin, ellagic acid, benzoic acid and Salicylic acid are the major phenolic compounds in Syzygium cumini leaves. Results of phenolic compounds analysis are nearly similar to those reported by Banerjee et al., (2005), who mentioned that the gallic acid equivalent phenolic content of Syzygium cumini on dry matter was $370 \mathrm{~g} \mathrm{Kg}^{-1}$. These results agree also with that of Veigas, et al., (2007), who reported that the Seeds are rich in gallic acid, ellagic acid. Also Daulatabad and Mirajkar (2006)., reported that Syzygium cumini seeds contain the phenolics such as ellagic acid, gallic acid, caffeic acid and ferulic acid and their derivatives.

Table ( 3 ) : Phenolic compounds of Syzygium cumini (L.) seeds and leaves.

\begin{tabular}{|c|c|c|}
\hline Phenolic compounds & $\begin{array}{c}\text { Syzygium cumini seeds } \\
\text { (mg/kg plant) }\end{array}$ & $\begin{array}{c}\text { Syzygium cumini leaves } \\
\text { (mg/kg plant) }\end{array}$ \\
\hline Gallic acid & 15.47 & 20.65 \\
\hline Catechol & 1.07 & 8.21 \\
\hline P-Hydroxy benzoic acid & 11.77 & 4.34 \\
\hline Caffeine & 4.56 & - \\
\hline Vanillic acid & 4.86 & 2.15 \\
\hline Syringic acid & - & 3.19 \\
\hline Vanillin & 22.78 & - \\
\hline P-Coumaric acid & 1.03 & - \\
\hline Ferulic acid & 5.47 & 2.93 \\
\hline Rutin & 7.57 & 60.34 \\
\hline Ellagic acid & 15.79 & 40.41 \\
\hline Benzoic acid & 244.14 & 289.98 \\
\hline O-Coumaric acid & 2.13 & 1.40 \\
\hline Salicylic acid & 0.5 & 64.22 \\
\hline Cinnamic acd & - & 1.36 \\
\hline
\end{tabular}


The plant phenols, because of their diversity and extensive distribution are the most important group of natural antioxidants. They posses several common biological and ch emical properties, namely antioxidant activity, the ability to scavenge both active oxygen species and to chelate metal ions, the potential for autoxidation , and the capability to modulate certain cellular enzyme activities ( Helser and Hotchkiss 1994).

\section{In vitro antioxidant activity ( DPPH} assay)

DPPH is a stable nitrogen-centered free radical, the color of which changes from violet to yellow upon reduction by either the process of hydrogen -or electron- donation. Substances which are able to perform this reaction can be considered as antioxidants and therefore radical scavengers (Dehpour et. al. 2009). In fact, free radical scavenging method (DPPH) show the reduction of alcoholic
DPPH solutions in the presence of an hydrogen donating antioxidant (Koleva et. al. 2002) and phenolic compound have been reported and provided to be potent hydrogen donators to the DPPH radical (Von et. al. 1997) because of their excellence structural chemistry (RiceEvans et. al. 1997). Figs. (1 and 2) shows the antioxidant potential Syzygium cumini seeds and leaves extracts. Extracts were further highlighted by the quenching of DPPH free radicals. The values of absorbance for seeds extracts ranged from 72.93 to 90.07 and 71.13 to 88.72 for leaves extracts compared with the values of absorbance for ascorbic acid ranged from 89.32 to 90.07 and followed the order of effectiveness as: ascorbic acid > seeds extracts > leaves extracts . In general, the seeds of the Syzygium cumini, exhibiting greater total phenolic and total flavonids content in the present analysis than leaves of the Syzygium cumini .

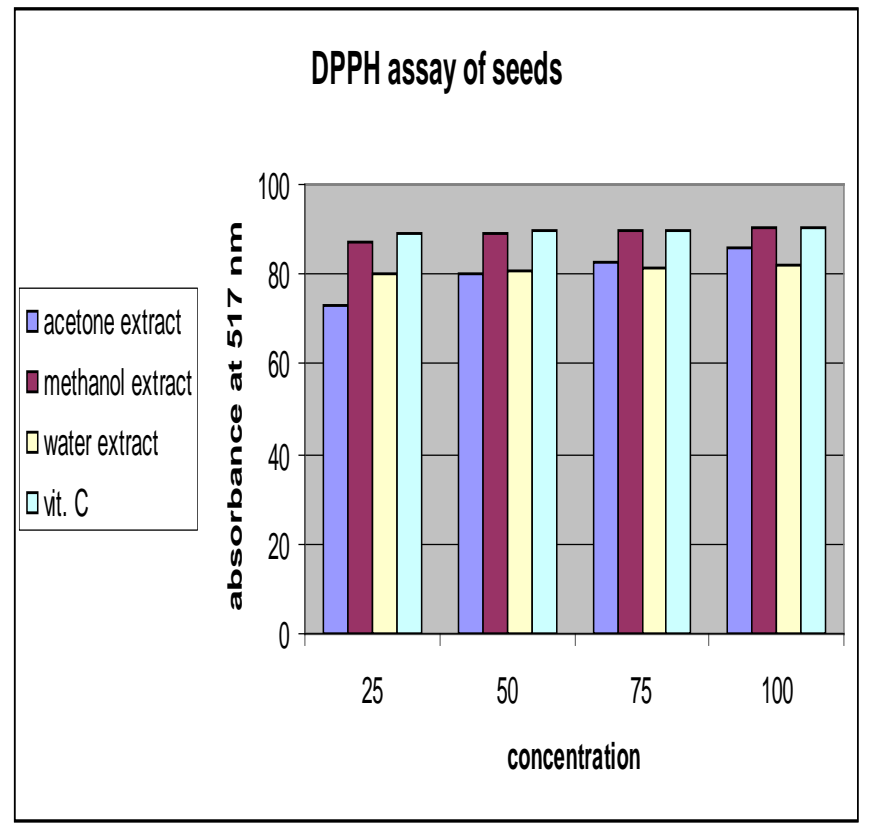

Fig. ( 1 ): DPPH assay of jamun seeds. 


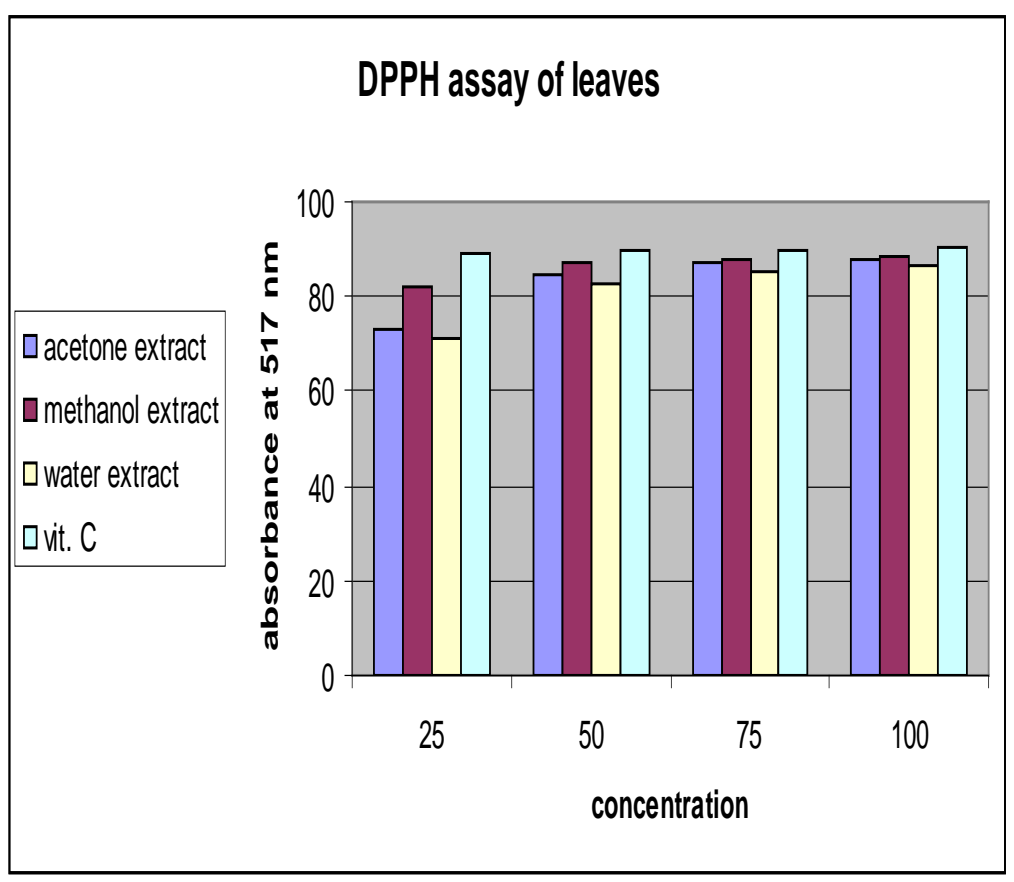

Fig. ( 2 ): DPPH assay of jamun leaves

Our data are in line with that of Elizabeth Margaret et al., (2015), who evaluated the antioxidant activity in methanolic extract of leaves, fruit pulp and seeds of Syzygium cumini, and he suggested that the phenolic compounds contribute effectively to the antioxidant activity. Also Hasan et al., (2009), were evaluated hydromethanol extracts of fifteen Bangladeshi medicinal plants for antioxidant potential using DPPH (1,1diphenyl-2-picryl hydrazyl) radical scavenging assay. Among the extracts Cocos nucifera, Caesalpinia pulcherrima, Punica granatum and Syzygium cumini were found displaying strong $\mathbf{( 9 0 \%}$ or more) DPPH radical scavenging action. Syzygium cumini exhibited the highest radical scavenging, with an $\mathrm{IC}_{50}$ value of $4.25 \mu \mathrm{g} / \mathrm{ml}$ compared to the ${ }^{\prime} C_{50}$ value of $5.15 \mu \mathrm{g} / \mathrm{ml}$ as shown by the reference antioxidant ascorbic acid, in a dose dependent fashion.
Impact of jamun seeds and leaves supplementation on the plasma lipid profile:

The data in Table 4 show the concentrations of different plasma lipids in all the groups. The results revealed that jamun seeds and leaves groups showed decreases in plasma triglycerides, total cholesterol, LDL-C, risk ratio and atherogenic index, and increases in HDL-C in comparison with the high fat group. Hyperlipidemia mainly increased the levels of cholesterol or LDL-C which is an important risk factor in the initiation and progression of atherosclerotic lesions Harrison et al., (2003). Our data are in line with that Pandey and Khan, (2002), who founded Syzygium cumini seeds is a highly viscous material. Highly viscous watersoluble fibers present in plant materials have been shown to reduce serum cholesterol levels and lipid levels in animals and human beings. 
M. A. Hammam, et al.,

Table (4): Effect of jamun seeds and leaves on lipid profile in rats feed on high fat diet:

\begin{tabular}{|c|c||c|c|c|c|c||}
\hline Group & $\begin{array}{c}\text { Triglycerides } \\
(\mathrm{mg} / \mathrm{dl})\end{array}$ & $\begin{array}{c}\text { cholesterol } \\
(\mathrm{mg} / \mathrm{dl})\end{array}$ & $\begin{array}{c}\text { HDL-C } \\
(\mathrm{mg} / \mathrm{dl})\end{array}$ & $\begin{array}{c}\text { LDL-C } \\
(\mathrm{mg} / \mathrm{dl})\end{array}$ & $\begin{array}{c}\text { Risk } \\
\text { ratio }\end{array}$ & $\begin{array}{c}\text { Atheroge } \\
\text { nic index }\end{array}$ \\
\hline \hline Control & $45.00 \pm 2 .^{\mathrm{c}}$ & $75.80 \pm 1.9^{\mathrm{a}}$ & $42.60 \pm 4.8^{\mathrm{b}}$ & 24.2 & 1.78 & 0.568 \\
\hline High fat & $82.40 \pm 2.5^{\mathrm{d}}$ & $121.00 \pm 3.5^{\mathrm{c}}$ & $25.80 \pm 1.3^{\mathrm{a}}$ & 78.72 & 4.69 & 3.05 \\
\hline J. Seeds & $55.80 \pm 1.9^{\mathrm{b}}$ & $98.20 \pm 3.1^{\mathrm{b}}$ & $37.20 \pm 7.8^{\mathrm{ab}}$ & 49.84 & 2.64 & 1.34 \\
\hline J.Leaves & $51.00 \pm 3.1^{\mathrm{a}}$ & $99.00 \pm 4.7^{\mathrm{b}}$ & $36.80 \pm 2.7^{\mathrm{ab}}$ & 52 & 2.69 & 1.41 \\
\hline
\end{tabular}

Means in the same column followed by the same letters do not differ significantly, and when the means followed by different letters differ significantly at $(p \geq 0.05)$.

Impact of jamun seeds and leaves supplementation on liver function:

In Table 5 the plasma AST, ALT and ALP activities were a significant $(P<0.05)$ increases in hyperlipidemic group when compared with control group. Oboh and Olumese (2010) recorded significant increases in the serum AST and ALT activities in rabbits fed a high fat diet (35\% palm oil) compared with the control group, fed a standard diet. Increases in serum activities of these enzymes are usually indicative of possible liver damage. In rats subjected to high fat diet with jamun seeds and leaves the enzyme liver marker indicate a decrease of AST , ALT and ALP as compared with hyperlipidemic group. These results agree with Sumaiya et al., (2017), they reported that, oral administration of methanolic extracts of $S$. cumini seeds (100 and $200 \mathrm{mg} / \mathrm{kg}$ body weight) showed beneficial effects including lowering blood glucose levels, improved heart and liver function, and hyperlipidemia . At 200 $\mathrm{mg} / \mathrm{kg}$, the extracts reversed cardiac and liver damage caused by alloxan.

\section{Impact of jamun seeds and leaves} on kidney function of hyperlipidemia rats:

Mean values of urea nitrogen and creatinine $(\mathrm{mg} / \mathrm{dl})$ for the groups of rats are illustrated in Table 6 . From these results, it could observe that there was non-significant difference $(P<0.05)$ between positive control group and group treated with jamun seeds and leaves for creatinine and urea nitrogen. Results agree with Sumaiya et al., (2017), they observed that, the methanolic extracts of S. cumini seeds (100 and 200 $\mathrm{mg} / \mathrm{kg}$ body weight) did not show any statistically significant reduction in plasma creatinine and plasma urea level in diabetic rats. 
Table (5) : Effect of jamun seeds and leaves on liver function in rats feed on high fat diet:

\begin{tabular}{|l||c||c|c||}
\hline Group & AST by (IU/L) & ALT by (IU/L) & ALP by (IU/L) \\
\hline Control & $96.40 \pm 1.140^{\mathrm{a}}$ & $41.40 \pm 1.140^{\mathrm{b}}$ & $281.40 \pm 2.608^{\mathrm{a}}$ \\
\hline \hline High fat & $113.00 \pm 3.808^{\mathrm{c}}$ & $53.20 \pm 2.588^{\mathrm{c}}$ & $335.00 \pm 2.915^{\mathrm{c}}$ \\
\hline \hline J. Seeds & $105.20 \pm 1.924^{\mathrm{b}}$ & $44.40 \pm 1.140^{\mathrm{a}}$ & $301.80 \pm 8.899^{\mathrm{b}}$ \\
\hline \hline J.Leaves & $107.40 \pm 1.140^{\mathrm{b}}$ & $46.00 \pm 2.449^{\mathrm{ab}}$ & $306.80 \pm 1.304^{\mathrm{b}}$ \\
\hline
\end{tabular}

Means in the same column followed by the same letters do not differ significantly, and when the means followed by different letters differ significantly at $(p \geq 0.05)$.

Table (6): Effect of jamun seeds and leaves on kidney function in rats feed on high fat diet:

\begin{tabular}{|c|c|c||}
\hline Group & $\begin{array}{c}\text { Creatinine } \\
(\mathrm{mg} / \mathrm{dl})\end{array}$ & $\begin{array}{c}\text { Urea nitrogen } \\
(\mathrm{mg} / \mathrm{dl})\end{array}$ \\
\hline \hline Control & $0.500 \pm 0.2049^{\mathrm{a}}$ & $53.40 \pm 6.877^{\mathrm{a}}$ \\
\hline High fat & $0.580 \pm 0.1451^{\mathrm{a}}$ & $56.00 \pm 3.674^{\mathrm{a}}$ \\
\hline J. Seeds & $0.480 \pm 0.1095^{\mathrm{a}}$ & $51.80 \pm 8.758^{\mathrm{a}}$ \\
\hline J.Leaves & $0.490 \pm 0.1000^{\mathrm{a}}$ & $54.60 \pm 11.803^{\mathrm{a}}$ \\
\hline
\end{tabular}

Means in the same column followed by the same letters do not differ significantly, and when the means followed by different letters differ significantly at $(p \geq 0.05)$.

\section{REFERENCES}

Ahmad, R., U.A. Muhammad, N. Tanzeela, A.Q. Saeed, H. Riaz and N.S. Muhammad (2015). Proximate Composition of Jamun (Syzygium cumini) Fruit and Seed. Journal of Agriculture \& Environmental Science, 15(7): 1221-1223

Allain, C.C., L.S. Poon, C.S.G. Chan, W. Richmond and P.C. Fu (1974). Clin Chem, 20: 470.

A.O.A.C., (1990). 15th Official methods of Analysis. Association Official Analysis Chemists, Washington D.C. USA. Pp. 807-928.
Banerjee, A., N. Dasgupta and De. Bratati (2005). In vitro study of antioxidant activity of Syzygium cumini fruit. Food Chemistry.90, 727-733.

Braca, A., N.D. Tommasi, L.D. Bari, C. Pizza, M. Politi and I. Morelli (2001). Antioxidant principles from Bauhinia terapotensis. J. Nat. Prod. 64: 892-895.

Campbell, J. A., (1961). Methodology of protein evaluation . RAG Nutrition Document R. 101 add. 37 , June meeting, New York.

Daulatabad, C.M.J., A.M. Mirajkar, K.M. Hosamani and G.M.M. Mulla (2006). Epoxy and cyclopropenoid fatty acids 
in Syzygium cumini seed oil. Journal of the Science of Food and Agriculture, 43, 91-94.5.

Dehpour, A.A., M.A. Ebrahimzadeh, S.F. Nabavi and S.M. Nabavi (2009). Antioxidant activity of methanol extract of Ferula assafoetida and its Essential oil composition, Grasas y Aceites 60 (4): 405-412.

Elizabeth Margaret, A. M. Shailaja and V. Venugopal Rao (2015). Int. J. Curr. Microbiol. App. Sci 4(9): 372-379

Fossati, F. and L. Prencipe (1982). Plasma triglycerides determined colorimetrically with an enzyme that produces hydrogen peroxide. J.Clin.Chem., 28 (10): 2077 - 2080.

Gupta, G.S. and D.P. Sharma (2013-2014). Triterpenoid and other constituents of Eugenia jambolana leaves. Phytochemistry 1974; 13

Harrison, D., K.G. Kathy, B. Horing and H. Drexler (2003). Role of oxidative stress in atherosclerosis .Am.J Cardiol.,91:7A-11A

Hasan, S.M.R., M.R. Md.Hossain, Akter, Jamila, M., Md.Mazumder, E.H. and S. Rahman (2009). DPPH free radical scavenging activity of some Bangladeshi medicinal plants, $\mathrm{J}$ medi plant res.3,875-879.

Hausamen, T. V., R. Helger, W. Rick and W. Gross (1967). Optimal conditions for the determination of serum alkaline phosphatase by a new kinetic method. Clin. Chem. Acta., 15: 241 245.

Helser, M.A. and J.H. Hotchkiss (1994). Comparison of tomato phenolic and ascorbate fractions on the inhibition of $\mathrm{N}$-nitroso compound formation. Journal of Agricultural and Food Chemistry. 42:129 - 132 .

Koleva, I.I., T.A. Van Beek, J.P.H. Linssen, A. De Groot and L.N. Evstatieva (2002). Screening of plant extracts for antioxidant activity: a comparative study on three testing methods. Phytochem. Anal., 13; 8-17.

Krauss, T. and N.A. Huschmand (2001). New evelopments in the treatment of cervical cancer. Onkologie, 24(4): 3405. doi: 10.1159/000055105. [PubMed] [Cross Ref].9-627.

Lopez, M.F., S. Stone, S. Ellis and J.A. Collwell (1977). Cholesterol determination in high density lipoproteins separated by three different methods. Clin.Chem.,23(5):882 - 886.

Nakamura, H., N. Izumiyama, K. Nakamura and K. Ohtsubo (1989). Age-associated ultra structural changes in the aortic intima of rats with diet induced hypercholesterolemia atherosclerosis . 79 (2-3): $101-111$.

Oboh, H.A. and F.E. Olumese (2010). Effects of Low Carbohydrate High Fat Nigerian-Like Diet on Biochemical Indices in Rabbits. Pakistan J. Nutr. 3, 245-249.

Pandey, M. and Aqueel Khan (2002). Hypoglycaemic effect of defatted seeds and water soluble fibre from the seeds of Syzygium cumini (Linn.) skeels in alloxan diabetic rats. niscaircsir.40.

Prasad, K, B. Janvel, R.K. Sharma and K. K. Prasad (2010). Compositional characterization of traditional medicinal plants: chemo-metric approach. Scholars Res. Lib. Archives Appl. Sci. Res., 2: 1-10.

Ravi, K., S. Rajasekaran and S. Subramanian (2005). Antihyperlipidemic effect of Eugenia jambolana seed kernel on Streptozotocin-induced diabetes in rats, Food Chem Toxicol,; 43: 14331439.

Retiman, S. and S. Frankel (1957). Colorimetric determination of GOT and GPT. Am. J. Clin. Path. 28:56. 
Rice-Evans, C.A., N.J. Miller and G. Paganga (1997). Antioxidant properties of phenolic compounds. Trends Plant Sci., 2; 152-159.

Sharma, S., B. K. Mehta, D. Mehta, H. Nagar and A. Mishra (2012). A review on pharmacological activity of Syzygium cumini extracts using different solvent and their effective doses. Int. Res. J. Pharmacol., 3: 5458.

Sumaiya Nahid, Kishor Mazumder, Zillur Rahman, Saiful Islam, Md. Humayun Rashid , Philip Grey Kerr (2017). Cardio and hepato-protective potential of methanolic extract of Syzygium cumini (L.) Skeels seeds : A diabetic rat model study. Asian Pac. J. Trop. Biomed., 7 (2): 126 - 133.

Stanley, M.P.P., N. Kamalakkannan, V.P Menon, J., (2003). Ethanopharmacol., 84 (2-3): 205- 209.
Veigas, J., M. Narayan, P. Laxman and B. Neelwarne (2007). Chemical nature, stability and bioefficacies of anthocyanins from fruit peel of Syzygium cumini Skeels. Food Chem, 105: 619-627.

Von Gadow A., E. Joubert and C.F. Hansmann (1997). Comparison of the antioxidant activity of rooibos tea (Aspalathus linearis) with green, oolong and black tea. Food Chem., 60: 73-77.

Young, DS. (2001). Effects of disease on clinical lab.tests. 4th ed AACC American Association for Clinical Chemistry .

Zuo, Y., H. Chen and Y. Deng (2002). Simultaneous Determination of Catechins Caffeine and Gallic acids in Green, Oolong, Black and Pu-err Teas using HPLC with a Photodiode Array Detector.Talanta,57: 307-316. 


\title{
التأثير الخافض للدهون لنبات البامبوزيا
}

\author{
مصطفي عبد الله همام، سمير عبد القادر القدوسي، صلاح منصور عبد الجواد، \\ رضا محمد ابراهيم راشد
}

قسم الكيمياء الحيوية الزراعية - كلية الزراعة - جامعة المنوفية

الملخص العربى

تهـف هذه الدراسـة إلى دراسـة التركيب الكيميائى لبذور وأولق نبات البامبوزيـا من ناحية محتواهـا من المركبات

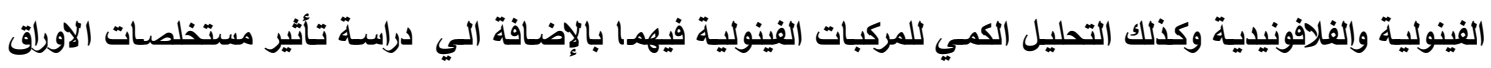
والبذور كمضادات أكسدة ، ثم بعد ذلك دراسة تأثير إضافة كل من هذه البذور والاولق لعليقه ذات محتوى دهنى مرتفع فى فئي

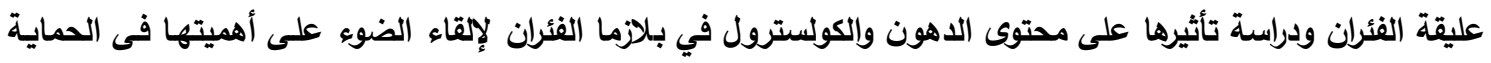

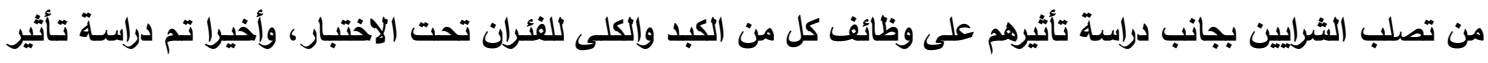

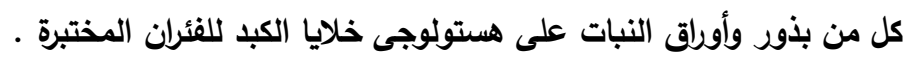

وكانت نتيجة المعاملة ببذور وأولق البامبوزيا أدت إلى خفض الزيادة الغير مرغوبة لكل قياسات الليبيدات المختلفة

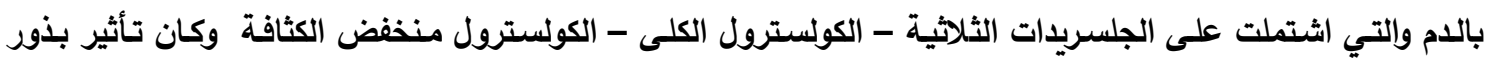
البامبوزيا يفوق مثيله في الأولقاق.

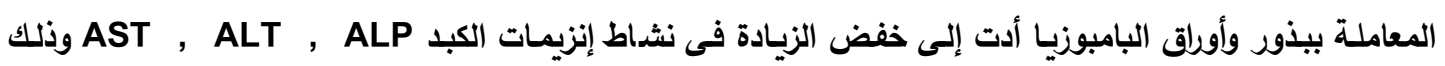
بالمقارنة بمجموعة الفئران المغذاة على العليقة عالية الدهون.

وأيضا لوحظ أن مجموعة الفئران المغذاة على العليقة عالية الدهون أظهرت نخلة الفرا بخلايا الكبد مرتبط بوجود التهابات مع وجود احتقان فى خلايا الكبد فى حين ان المعاملة ببذور وأورلق نبات البامبوزيا عملت على استرجاع الخلايا لوضعها الطبيعي.

أسماء السادة المحكمـون:

كلية الزراعة - جامعة الزقازيق أ.د. رجب عبدالفتاح المصرى الميدين

كلية الزراعة - جامعة المنوفية

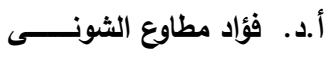

